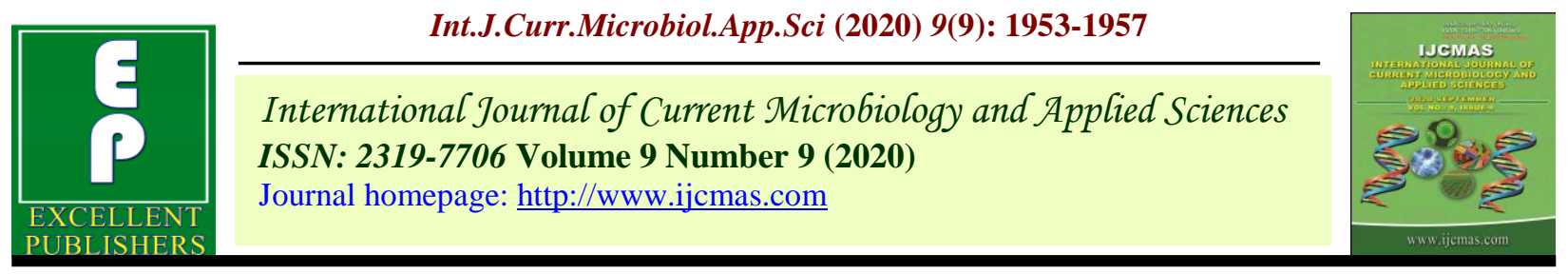

Original Research Article

https://doi.org/10.20546/ijcmas.2020.909.245

\title{
Effect of Doramectin on Biochemical Alteration in Mange Infested Camel
}

\author{
N. R. Pandya ${ }^{1 *}$, G. C. Mandali ${ }^{1}$, K. M. Dave ${ }^{1}$, S K. Raval ${ }^{1}$, \\ S. K. Bhavsar ${ }^{2}$ and A. C. Patel $^{3}$ \\ ${ }^{1}$ Department of Veterinary Medicine, College of Veterinary Science \& Animal Husbandry, \\ Anand Agricultural University, Anand-388001, India \\ ${ }^{2}$ Department of Veterinary Pharmacology and Toxicology, College of Veterinary Science \& \\ Animal Husbandry, Anand Agricultural University, Anand-388001, India \\ ${ }^{3}$ Department of Animal Genetics and Breeding, College of Veterinary Science \& Animal \\ Husbandry, Anand Agricultural University, Anand-388001, India \\ *Corresponding author
}

\section{A B S T R A C T}

Keywords

Doramectin,

Biochemical alteration, Camel

Article Info

Accepted:

15 August 2020

Available Online:

10 September 2020
Mange in camel caused by Sarcoptesscabiei var cameli, is considered to be one of the most contagious, zoonotic and debilitating diseases of camels. A total of 7camels infested with mange were selected from those presented at Veterinary Clinical Complex of the College, in Anand and from surrounding villages. The diagnosis was carried out by skin scrapping examination. All the camels were treated with doramectin @ $200 \mu \mathrm{gm} / \mathrm{kg}$ B. wt. once in a week. The biochemical parameters, viz., serum total protein and alanine aminotransferase were found significantly $(\mathrm{p}<0.05)$ higher on $35^{\text {th }}$ day in comparison to day ' 0 '. The serum creatinine and aspartate aminotransferase were decreased significantly $(\mathrm{p}<0.05)$ on $35^{\text {th }}$ day in comparison to day ' 0 '.

\section{Introduction}

Camels are exposed and affected by a range of ectoparasites causing a loss in body condition, health and productivity. Some biting insects act as vectors for Trypanosoma evansi and mite Sarcoptes scabiei that cause trypanosomiasis and sarcoptic mange, respectively (Higgins, 1986). Sarcoptic mange, caused by Sarcoptess cabiei var cameli, is considered to be one of the most contagious, zoonotic and debilitating diseases of camels and Llamas (Jarso et al., 2018).
Sarcoptes is known as burrowing mite and it pierces deeply through the skin surface and lead to intense pruritus and exudative dermatitis (Kumar et al., 1992; Amer et al., 2006). The mange infestation is usually considered to be a seasonal disease, mainly reported in the months of winter or in cold weather with had an acute course (Dinka et al., 2010). Diagnosis of camel mange by skin scraping examination to identify the mange mite (Feyera et al., 2015). Blood samples collected for the biochemical analysis showed significantly lower values of total protein, 
albumin, globulin, A:G ratio and calcium (Parmar and Singh, 2005). Based on clinical examination and laboratory findings, the camel is administered with microcyclic lactone such as ivermectin or doramectin along with multivitamins and minerals supplement (Palanivelrajan et al., 2015).

\section{Materials and Methods}

In present study 7 camels suffering from mange infestation were presented at the Veterinary Clinical Complex (VCC), Veterinary College, Anand, and nearby villages of Anand district. The skin scrapping of all these animals was done. The $8 \mathrm{ml}$ blood was collected in clot activator vials for serum. The blood was collected on weekly interval to study the biochemical parameters. All camels were treated with doramectin @ $200 \mu \mathrm{gm} / \mathrm{kg}$ b.wt once in a week. The serum biochemical parameters studied included, Total protein (g/dl), Creatinine (mg/dl), Alanine amino transferase - ALT (U/L), and Aspartate amino transferase - AST (U/L) by using standard assay kits with the help of Clinical Serum Biochemistry Auto-analyser (CKK 300). The data was analyzed by using completely randomized design as per Snedecor and Cochran (1994).

\section{Results and Discussion}

The results of biochemical values presented in Table 1. The mean values of total protein $(\mathrm{g} / \mathrm{dl})$ increased gradually and significantly $(\mathrm{p}<0.05)$ with increasing the duration of treatment till $21^{\text {st }}$ day $(7.37 \pm 0.89)$ in comparison to the values of previous week. However, the improvement in total protein values was non-significant from $28^{\text {th }}$ day $(7.63 \pm 0.77)$ to $35^{\text {th }}$ day $(7.46 \pm 0.86)$. The low value of total protein is attributed to seepage of protein through exudation, extravasation of fluids to interstitial tissues and tunnels made by mites. Singh and Gahlot (2000) reported significant decrease in total protein levels at pre-treatment which increased significant in post treatment stage. Similar findings were reported by Kamal (2008), Parmar et al., (2005), Dixit et al., (2009), Arul (2016) and Varia et al., (2018).

The mean values of serum creatinine $(\mathrm{mg} / \mathrm{dl})$ decreased gradually and significantly $(\mathrm{p}<0.05)$ with increasing the duration of treatment till $21^{\text {st }}(1.22 \pm 0.43)$ and $35^{\text {th }}$ day $(0.95 \pm 0.41)$ in comparison to the values of previous week. Singh et al., (2003) reported significant increase in serum creatinine levels in mange affected camels in comparison to healthy camels. Similar finding was reported by Kamal (2008).

The mean values of alanine aminotransferase (U/L) increased gradually and significantly $(\mathrm{p}<0.05)$ on $14^{\text {th }}(21.06 \pm 0.17)$ and $21^{\text {st }}$ day $(21.19 \pm 0.10)$ in comparison to day ' 0 ' $(20.20 \pm 0.13)$ and $14^{\text {th }}$ day $(21.06 \pm 0.17)$. The improved in ALT values was nonsignificant from $21^{\text {st }}$ day $(21.19 \pm 0.10)$ to $35^{\text {th }}$ day $(21.16 \pm 0.23)$. The values of AST and ALT varies according to the liver function which is associated with the physiological and health conditions of the animal, Dixit et al., (2009) reported decrease in alanine aminotransaminases in the camels suffering from sarcoptes mange infestation. Similar trend also has been reported by Varia et al., (2018).

The mean values of aspartate aminotransferase (U/L) decreased gradually and significantly $(\mathrm{p}<0.05)$ on $7^{\text {th }}(75.06 \pm$ $0.58), 14^{\text {th }}(68.88 \pm 0.85), 21^{\text {st }}(65.30 \pm 0.67)$, $28^{\text {th }}$ day $(61.81 \pm 0.92)$ and $35^{\text {th }}$ day $(61.75 \pm$ $0.67)$ in comparison to 0 day $(79.84 \pm 1.01)$. However, the decrease was non-significant on $35^{\text {th }}$ day $(61.75 \pm 0.67)$ in comparison to value on $28^{\text {th }}$ day $(61.81 \pm 0.92)$. Premalatha et al., (2010) found the increased level of aspartate aminotransferase (AST) in mangy camels in captivity. Similar findings were also reported by Arul (2016). 
Table.1 Serum biochemical findings in mange infested camels on different treatment day

\begin{tabular}{|c|c|c|c|c|}
\hline $\begin{array}{c}\text { Days of } \\
\text { treatment }\end{array}$ & $\begin{array}{c}\text { Total Protein } \\
(\mathbf{g} / \mathbf{d l})\end{array}$ & $\begin{array}{c}\text { Serum } \\
\text { Creatinine } \\
(\mathbf{m g} / \mathbf{d l})\end{array}$ & $\begin{array}{c}\text { ALT } \\
(\mathbf{U} / \mathbf{L})\end{array}$ & $\begin{array}{c}\text { AST } \\
(\mathbf{U} / \mathbf{L})\end{array}$ \\
\hline $\mathbf{0 ~ d a y}$ & $6.21^{\mathrm{a}} \pm 0.18$ & $2.59^{\mathrm{e}} \pm 0.14$ & $20.20^{\mathrm{a}} \pm 0.13$ & $79.84^{\mathrm{e}} \pm 1.01$ \\
\hline $\mathbf{7}^{\text {th }}$ day & $6.54^{\mathrm{a}} \pm 0.13$ & $2.09^{\mathrm{d}} \pm 0.11$ & $20.58^{\mathrm{a}} \pm 0.15$ & $75.06^{\mathrm{d}} \pm 0.58$ \\
\hline $\mathbf{1 4}^{\text {th }}$ day & $6.98^{\mathrm{b}} \pm 0.12$ & $1.64^{\mathrm{c}} \pm 0.10$ & $21.06^{\mathrm{b}} \pm 0.17$ & $68.88^{\mathrm{c}} \pm 0.85$ \\
\hline $\mathbf{2 1}^{\text {st }}$ day & $7.37^{\mathrm{c}} \pm 0.89$ & $1.22^{\mathrm{b}} \pm 0.43$ & $21.19^{\mathrm{b}} \pm 0.10$ & $65.30^{\mathrm{b}} \pm 0.67$ \\
\hline $\mathbf{2 8}^{\text {th }}$ day & $7.63^{\mathrm{c}} \pm 0.77$ & $1.03^{\mathrm{a}} \pm 0.43$ & $21.32^{\mathrm{b}} \pm 0.98$ & $61.8^{\mathrm{a}} \pm 0.92$ \\
\hline $\mathbf{3 5}^{\text {th }}$ day & $7.46^{\mathrm{c}} \pm 0.86$ & $0.95^{\mathrm{a}} \pm 0.41$ & $21.16^{\mathrm{b}} \pm 0.23$ & $61.75^{\mathrm{a}} \pm 0.67$ \\
\hline
\end{tabular}

Mean $( \pm$ SE)

Means with uncommon superscripts within the column (a,b,c,d,e) differ significantly $(\mathrm{p}<0.05)$.

Table.2 Trace mineral level in mange infested camels on different treatment day Mean $( \pm \mathrm{SE})$

\begin{tabular}{|c|c|c|}
\hline $\begin{array}{c}\text { Days of } \\
\text { treatment }\end{array}$ & Copper $(\boldsymbol{\mu g} / \mathbf{d L})$ & Zinc $(\boldsymbol{\mu g} / \mathbf{d L})$ \\
\hline $\mathbf{0 ~ d a y}$ & $118.47^{\mathrm{d}} \pm 3.32$ & $81.38^{\mathrm{a}} \pm 2.06$ \\
\hline $\mathbf{7}^{\text {th }}$ day & $106.05^{\mathrm{c}} \pm 3.77$ & $85.97^{\mathrm{ab}} \pm 1.77$ \\
\hline $\mathbf{1 4}^{\text {th }}$ day & $96.75^{\mathrm{b}} \pm 3.71$ & $90.43^{\mathrm{bc}} \pm 1.96$ \\
\hline $\mathbf{2 1}^{\text {st }}$ day & $88.63^{\mathrm{ab}} \pm 2.83$ & $91.61^{\mathrm{c}} \pm 1.62$ \\
\hline $\mathbf{2 8}^{\text {th }}$ day & $83.92^{\mathrm{a}} \pm 2.09$ & $93.62^{\text {cd }} \pm 1.17$ \\
\hline $\mathbf{3 5}^{\text {th }}$ day & $85.31^{\mathrm{a}} \pm 1.90$ & $97.56^{\mathrm{d}} \pm 1.10$ \\
\hline
\end{tabular}

Means with uncommon superscripts within the column $(\mathrm{a}, \mathrm{b}, \mathrm{c}, \mathrm{d})$ differ significantly $(\mathrm{p}<0.05)$.

\section{Trace mineral estimation}

The results of trace mineral level are presented in Table 2. The mean values of copper decreased gradually and significantly $(\mathrm{p}<0.05)$ with increasing the duration of treatment till $28^{\text {th }}$ day $(83.92 \pm 2.09 \mu \mathrm{g} / \mathrm{dL})$ in comparison to the values of previous week. However, the decline in copper values was non-significant on $35^{\text {th }}$ day $\left(85.31^{\text {a }} \pm\right.$ $1.90 \mu \mathrm{g} / \mathrm{dL})$ in comparison to $28^{\text {th }}$ day $\left(83.92^{\mathrm{a}}\right.$ $\pm 2.09 \mu \mathrm{g} / \mathrm{dL}$ ). Baksh (2000) and Dongre (2000) recorded serum copper level in healthy camel of different breeds, age groups and both sexes. Dixit et al., (2008) stated that copper value was significantly increased in mange infested camels.

The mean values of zinc increased gradually and significantly $(\mathrm{p}<0.05)$ on $21^{\text {st }}$ day $(91.61$ $\pm 1.62 \mu \mathrm{g} / \mathrm{dL})$ and $35^{\text {th }}$ day $(97.56 \pm$ $1.10 \mu \mathrm{g} / \mathrm{dL})$ in comparison to $14^{\text {th }}$ day $(90.43$ $\pm 1.96 \mu \mathrm{g} / \mathrm{dL})$ and $28^{\text {th }}$ day $(93.62 \pm$ $1.17 \mu \mathrm{g} / \mathrm{dL}$ ) and non-significantly increased on $7^{\text {th }}\left(85.97^{\text {ab }} \pm 1.77 \mu \mathrm{g} / \mathrm{dL}\right), 14^{\text {th }}(\mu \mathrm{g} / \mathrm{dL})$ and $28^{\text {th }}$ day $(\mu \mathrm{g} / \mathrm{dL})$ in comparison to the values 
of previous week. Singh et al., (2003) observed significantly decreased value of zinc in mange affected camels. Similarly finding was reported by Dixit et al., (2008).

\section{Acknowledgement}

We thank to the Dean, Veterinary College, Anand; Professor and Head, Veterinary Clinical Complex and the authorities of Anand Agricultural University, Anand for the facilities and cooperation provided for this work.

\section{References}

Amer, A., Abou, El-Ela. A., and Ratib, H. 2006. Some haemato-biochemical studies on Sarcoptic mange infested camels before and after treatment by doramectin at Assiut governorate. Proceedings of the International Scientific Conference of Camel, Saudi Arabia, pp. 686- 691.

Arul, V. 2016. Therapeutic management of scabies in a captive camel. International Journal of Current Research, 8(3), 27768-27772.

Baksh, A.A. 2000. Zinc values and red blood cells count of camel (Camelus dromedarius) in Saudi Arabia. Pakistan Veterinary Journal, Vol. 20 (4), 173 176.

Dinka, A., Eyerusalem, B., and Yacob, H. T. 2010. A study on major ectoparasites of camel in and around Dire Dawa, eastern Ethiopia. Revue de Medicine Veterinaire, 161(11), 498-501.

Dixit, S. K., Singh, A. P., and Tuteja, F. C. 2009. Evaluation of therapeutic efficacy of herbal formulation with and without levamisol against mange in dromedary camel. Veterinary Practitioner, 10(2), 141-144.

Dixit, S.K., Singh, A.P., Dadhich, H., Sharma, T., and Rathore, A. 2008.
Biochemical and histopathological studies of sarcopticosis in camel (Camelus dromaderius). Indian Journal of Veterinary Pathology, 32(1), 59-61.

Dongre, R. A. 2000. Haemato-biochemical studies in relation to trace mineral status in camel (Camelus dromedarius). M.V.Sc. Thesis. Rajasthan Agricultural University, Bikaner, India.

Feyera, T., Admasu, P., Abdilahi, Z., and Mummed, B. 2015. Epidemiological and therapeutic studies of camel mange in Fafan zone, Eastern Ethiopia. Parasites and Vectors, 8(1), 612.

Higgins, A. J. 1986. Common ectoparasites of the camel and their control.British Veterinary Journal, 141(2), 197-216.

Jarso, D., Birhanu, S., and Wubishet, Z. 2018. Review on epidemiology of camel mange mites. Biomedical Journal of Scientific and Technical Research, 8(1), 6313-6316.

Kamal, A. M. 2008. Some biochemical, hematological and clinical studies of selected ruminal and blood constituents in camels affected by various diseases. Research Journal of Veterinary Science., 1, 16-27.

Kumar, D. S, Raisinghani, P. M., and Manohar, G. S. 1992. Sarcoptic mange in camels: A review. Proceedings of the First International Camel Conference, Dubai, UAE, pp. 79-82.

Palanivelrajan, M., Thangapandian, M., and Prathipa, A. 2015. Therapeutic management of sarcoptic mange in a camel (Camelus dromedarius). Journal of Wildlife Research, 3(1), 5-7.

Parmar, A. J., and Singh, V. 2005. Efficacy of doramectin and ivermectin against sarcoptic mange in camels. Journal of Veterinary Parasitology, 19(2),159-160.

Parmar, A. J., Singh, V., Chaudhary, S. S., Prajapati, B. H., and Sengar, Y. S. 2005. Haemato-biochemical studies on 
sarcoptic mange in camel (Camelus dromedarus) in Banaskantha district (North Gujarat). Journal of Parasitic Diseases, 29(1), 71-73.

Premalatha, N., Jayathangaraj, M. G., Senthilkumar, K., Senthilvel, K., Vengadabady, N., and Muralimanhar, B. 2010. Strategic treatment of scabies in captive camels (Camelus dromedarius) in Tamilnadu. Journal of Veterinary and Animal Science, 6(4), 188-190.

Singh A.P., and Gahlot, A.K. 2000.Studies on sarcoptic mange in camels. Veterinary
Practitioners, 1(1), 13-17.

Singh, I., Khurana, R., and Khokhar, R. S. 2003. Serum biochemical alteration in mangy camels. Haryana Veterinarian, $42,48-50$.

Snedecor, G. W. and Cochran, W. G. 1994. Statistical Methods. ( $8^{\text {th }}$ ed.). The Iowa State University Press, Ames, Iowa, USA.

Varia, T., Prajapati, A., and Raval, S. 2018. Haemato-biochemical changes in mange infection in camels. Life Sciences Leaflets, 98, 26.

\section{How to cite this article:}

Pandya, N. R., G. C. Mandali, K. M. Dave, S. K. Bhavsar and Raval, S. K. 2020. Effect of Doramectin on Biochemical Alteration in Mange Infested Camel. Int.J.Curr.Microbiol.App.Sci. 9(09): 1953-1957. doi: https://doi.org/10.20546/ijcmas.2020.909.245 